\section{DANCING OR STRICKEN PEACOCK? THAN SHWE, SUU KYI AND THE POLITICS OF INSTITUTIONAL CHANGE IN MYANMAR}

\section{Helen James ${ }^{1}$}

\section{Abstract}

In a country where signs, symbols and astrology have played key roles in its political and cultural evolution, the peacock as the emblem of an independent state has had a chequered history in Myanmar (Burma). Frequently juxtaposed to the Sheldrake, emblem of the Southern Mon kingdom centred on Pegu until incorporation into the larger Burmese empire in the mid- $18^{\text {th }}$ century, the country peacock could not withstand the advances of the rampant British lion during the $19^{\text {th }}$ century. It is now a protected bird accorded sanctuary, and placed on a pedestal with reverence almost equal to that of the sacred 'White Elephant' found recently in the jungles of Arakan. Such indigenous institutions are playing a critical role as the transitional state of Myanmar seeks to transform its political and socio-economic fabric after 26 years of socialist policies (1962-1988). In analyzing the politics of institutional change in contemporary Myanmar, we are forced to take account of Muthiah

${ }^{1}$ Ph.D.,Visiting Fellow, Centre of International Studies and Clare Hall, Cambridge University. She is also a Visiting Fellow with the Asia Pacific School of Economics and Government and the Research School of Pacific and Asian Studies, the Australian National University. Her field of research in Thai/Myanmar Studies.
Alagappa's observation that transitional states are not necessarily in linear evolution to Western models of democratic governance, for this expected trajectory 'has not been borne out in practice' whilst 'politics in developing countries has its own dynamics.' Alagappa's views resonate also in the writings of Robert Taylor who notes the complexity and problematic task of grafting multi-party democratic systems onto societies like Myanmar with weak traditions of civil society, low levels of economic development and patronclientalist politico-social structures. ${ }^{3}$ The following paper focuses on some of the key political and socio-economic issues at the heart of achieving evolutionary institutionai change in Myanmar (Burma).

\section{Introduction}

In his two well-known books on the failing fortunes of the monarchical state of Burma, the former Rector of Rangoon (Yangon) University, Professor Dr. Htin Aung, presented an incisive analysis of the fate of the indigenous institutions of this small Southeast Asian country during the height of the colonial era: the failure to uphold the central role of the Buddhist Sangha, the destruction of the monarchy, and the subordination of Burmese culture as the traditional state identity to that of British India. His volume, Lord Randolph Churchill and the Dancing Peacock: the British Conquest of Burma, 1885, tells the story of the political machinations of the Secretary of State for India at the time of

\footnotetext{
${ }^{2}$ Muthiah Alagappa. 1995. Pólitical Legitimacy in Southeast Asia: the Moral Question. Stanford: Standford University Press, p.5.

${ }^{3}$ Robert H Taylor. 1987. The State in Burma. Honolulu: University of Hawaii Press.
} 
the Third Anglo-Burmese War in 1885, which resulted in the remainder of Upper Burma, with its capital at Mandalay, being annexed in 1886 a s a province of $B$ ritish India. U Htin Aung's other volume, The Stricken Peacock: Anglo-Burmese Relations 1752-1948, analyses, from the Burmese perspective, the changing pattern of British interactions with the Konbaung Dynasty, resulting in the gradual dissection of Burma in the three wars fought with Britain during the nineteenthcentury (1824-1826; 1852; 1855), up to the re-gaining of Burma's independence on 4 January $1948 .{ }^{4}$ In both volumes U Htin Aung uses the peacock as the symbol of the indigenous monarchical state of independent Burma. ${ }^{5} \mathrm{U}$ Htin Aung's evocation of the peacock imagery dancing or stricken - thus powerfully suggests Burma's efforts to sustain its autonomous existence as an independent state, and its agony as that independence was extinguished.

The peacock has long been associated with royalty and state power, not just in BurmaMyanmar, but also in other countries such as India and Iran. In contemporary Myanmar, the peacock is again a protected bird which none may keep without a licence. In a country where signs, symbols and astrology imbue the very fabric of everyday existence and determine many

\footnotetext{
${ }^{4}$ In this paper, the word Burma designates the state before 1988; M yanmar refers to the state after 1988, when the country's name was officially changed by the government of the day and registered with the United Nations.

5 Htin Aung. 1990. Lord Randolph Churchill and the Dancing Peacock: British Conquest of Burma. 1885. Daryaganj. India: Manohar, 1990: Htin Aung. 1965. The Stricken Peacock: AngloBurmese Relations 1752-1948. The Hague: Nijhoff.
}

major decisions - private as well as public - the royal history of the peacock sanctifies its association. ${ }^{6}$ As emblem of the Konbaung dynasty, the last indigenous Burmese empire, which in 1757 overcame the Sheldrake, emblem of the Southern Mon kingdom based on Pegu, the peacock is associated with power and political legitimacy. It is evocative of those indigenous institutions which the state of Myanmar appears to be seeking to recover from its monarchical past.

The symbolism of the peacock takes on additional significance in the context of a recent local tale. The story goes like this: two beautiful peacocks used to live in one of the foreign embassies in Yangon. Named Than Shwe and Suu Kyi, the two peacocks were inseparable; where one went, the other followed as surely as day follows night. Then one day the peacock, Than Shwe, went belly-up, feet in the air, and died. The peacock, Suu Kyi, was inconsolable. She mourned, wandered away, and was never seen again.

In Myanmar, where astrology has determined some key political and economic decisions, the story of two peacocks has overtones of political allegory. ${ }^{7}$ Long time Myanmar observers,

6 Burmese people traditionally do not take family names; when a child is born he/she receives a name in accordance with the day of the week on which birth occurred and in accordance with the astrologer's advice. A Burmese colleague told me that he changed his name when advised by the astrologer that his name would bring him into conflict with his father in later life. The new name also given by the astrologer.

${ }^{7}$ For example, during the time of the late dictator, General Ne Win, a series of the demonetizations, 
watching the ebb and flow of the political reconciliation process brokered by UN Special Envoy, Tun Razali Ismail, have often pondered the apparently symbiotic relationship b etween the $\mathrm{C}$ hairman of the State Peace and Development Committee (SPDC), Senior General Than Shwe, and his bete noire, opposition leader, Daw Aung San Suu Kyi, General-Secretary of the National League for Democracy (NLD), the amalgam of disparate political groups which won over 60 per cent of the votes in the May 1990 elections, but which the military government in Myanmar has never permitted to govern.

Looking at the political fortunes of Myanmar since the 30 May 2003 incident, one might ask: Will the country survive as a dancing peacock trying to retain its autonomy -or will it become the stricken bird of history? The fate of the peacock is integral to the strategic decisions being taken high level to try to ensure a prosperous future for the country. In this regard, another indigenous emblem enters the picture, the two sacred white elephants which in 2002 were found in the jungles of Arakan. Considered an embryo Buddha, the sacred white elephants is considered to presage great good fortune and prosperity for the country. In past history, possession of the sacred white elephants was the belli for wars between Burma and its neighbour, Siam, in the $16^{\text {th }}-18^{\text {th }}$ centuries. As might be expected of such an emblem, white elephants are specially housed, clothed and tendered, befitting the symbolism of their station. ${ }^{8}$ To realize this prosperity,

which immediately impoverished the middle class, was guided by his penchant for astrology and numerology. Currency was re-issued in denominations of nine, which he considered his lucky number. His sixth (brief) marriage was also determined by astrology. the country's leaders will need to chart, astutely, an extraordinarily complex path in order to restore the political and socioeconomic fortunes of the state.

\section{Dramatic Personae}

Senior General Than Shwe, Chairman of the SPDC and Commander-in-Chief of the Defence Services, has been both Head of Government and Head of State since 1992. Following the elevation of the former Secretary-1, General Khin Nyunt, to the position of Prime Minister on 25 August 2003, Senior General Than Shwe relinquished the role of Head of Government to General Khin Nyunt as Prime Minister. Senior General Than Shwe is reputed not to favour the glare of public life and to have been wishing to retire for some time. $\mathrm{He}$ is also known to have an intense aversion towards Daw Aung San Suu Kyi, whose name is not to be mentioned in his presence.

In early October 2003, the Myanmar Times, the English language newspaper in Yangon, whose editor is Australian, Ross Dunkley, and whose overall control comes under that of the new Prime Minister, printed an article stating that General Than Shwe had retired (from being Head of Government); that the Prime Minister would henceforth take responsibility for economic management, while Vice-Senior General Maung Aye would take responsibility for the armed forces. Vice Senior General Maung Aye is currently Vice-Chairman of the SPDC and Deputy Commander-in-Chief of the Defence Services. The SPDC is the military junta which has governed the country since 1988, initially as the State Law and Order

8 I was taken to see the sacred white elephant in November 2002. 
Restoration Council (SLORC), then, since 1997 , as the SPDC. It has an indeterminate number of members and should not be confused with the Cabinet, which is a separate entity of 35 minutes, 10 of whom currently are civilians.

On the operational side, under the Prime Minister, are the new Secretary-1. Lt. General Soe Win, and the new Secretary2, Lt. General Thein Sein. Lt. General Soe Win was previously the Regional Commander of the North Western division in Upper Myanmar, where the 30 May 2003 incident took place. Following a series of speeches criticizing Daw Aung San Suu Kyi in early 2003, he was elevated to fill the post of Secretary-2, left vacant for some time by the death in 2002 of then Secretary-2, General T in Oo (not to be confused with the General Tin Oo who is Deputy General Secretary of the NLD). In the re-organization of the responsibilities of the top structure announced on 25 August 2003, Lt. General Soe Win was promoted to the position of Secretary-1, indicative of having performed well and to the satisfaction of Senior General Than Shwe in his previous position. At this stage, little is known of the new Secretary-2, Lt. General Thein Sein.

Under the division of responsibilities prior to 25 August, General Khin Nyunt as Secretary-1 had control of the resources of the Military Intelligence Service (MIS). This led some commentators to surmise that his move to Prime Minister was a 'demotion.' In Myanmar political culture, this is a puzzling interpretation; not only does the new Prime Minister have at his command the resources of MIS, but also of all other components of the state apparatus. To re-inforce the public image of his elevation, photo opportunities portrayed the Prime Minister seated on a higher level than that of Secretary-1 and Secretary-2. Preceived to be a reformer who has fostered Myanmar's reengagement with the international community, the new Prime Minister now has responsibility for steering Myanmar through the complex tasks associated with the restoration of democracy in the country, and reviving the economy of this very poor nation, which was declared a Least Developed Country (LDC) in 1987.

Since September 2003, the new roles of the Senior General and the Prime Minister have been delineated in a series of state visits by foreign dignitaries from India, Thailand and other Asian countries. In each case, the President of the foreign polity is received by Senior General Than Shwe, suggesting that the position of Chairman of the SPDC might be being transformed into that of a ceremonial President similar to the situation with pertained in Myanmar shortly after independence; whereas the role of the Prime $\mathrm{M}$ inister is c learly that of $\mathrm{H}$ ead of Government. He receives his counterparts, attended the $9^{\text {th }}$ ASEAN summit in Bali, 78 October 2003, and held consultations with the Premier of China, Wen Jiao-bao. It is likely that the final shape of the top structure may continue to evolve further as decisions are made concerning the composition of the country's legislative bodies once a new constitution is promulgated.

On the opposite bench is Daw Aung Sana Suu Kyi, Nobel Peace Prize winner and daughter of independence leader, General Aung San, who was assassinated along with five members of his cabinet by former premier, U Saw, and his associates

9 Sydney Morning Herald, 8 October 2003. 
on 19 July 1947. As General-Secretary of the NLD, she has been a focal point for the movement to restore democracy to Myanmar since her return to the country in 1988. Charismatic in personality and determined in her stance, she has been seen as the beacon of hope for all those who have suffered under military rule since the coup in 2 March 1962, which brought the military, under the late General Ne Win, to power.

In Myanmar political culture, Daw Aung San Suu Kyi appears to take on the characteristics of the minlaung, the saviour of the country, and is so presented in the international press. There have been many such figures in Burmese-Myanmar history, but few have succeeded, the last notable success being Alaunghpaya (1752-1760), the first monarch of the last indigenous Burmese dynasty, the K onbaung D ynasty (1752-1885). Raising his standard in the north at Shwebo, from whence various other pretenders have since tried their fortunes, Alaunghpaya gathered his forces to finally overwhelm his Mon opponents at Pegu in 1757. The north of Myanmar, around Shwebo and beyond, has a long tradition of hosting the minlaung. In this part of the country, the Padein Prince in 1866 sought unsuccessfully to challenge his uncle, King Mindon; here in the north, the Limbin Prince raised his standard, also unsuccessfully, against British colonial occupation in 1886. The Chaunggwa prince and the Myinzaing princes, in the same period, did likewise. Upper Myanmar thus evokes powerful traditions of challenges to central authority by charismatic figures.

When Daw Aung San Suu Kyi went north in May 2003, the thirteenth anniversary of the unacknowledged election victory, she reportedly held discussions with the
Kachin Independence Army (KIA), then proceeded south towards Sagaing province, the former royal precinct just outside Mandalay, known to be a stronghold of staunchly nationalist (and socialist) sentiments among the population. Sagaing is also the region previously under the command of the new Secretary-2, Lt. General Soe Win. In monarchical times, Sagiang hosted a series of royal capitals and was the area delineated for the ahmudan class to live, that group which served the royal power and did not pay taxes (as distinct from the athi, who paid taxes, but were exempt from royal service). Accompanied by an ever-increasing number of followers, Daw Aung San Suu Kyi's progress would have had the overtones of a royal cavalcade, which could not but be interpreted as a direct challenge, by a potential minlaung, to the central authority. On hearing of her progress, Senior General Than Shwe is reported to said, 'Do we have to put up with this?' Those nearby reportedly heard and acted on it. ${ }^{10}$

\section{Political Culture}

Since 1988, Myanmar may be characterized as a transitional state seeking to evolve to a market economy after 26 years of socialist autarky (1962-1988). In 1988-89 the legislative framework for the former socialist economy was officially abrogated and replaced by a series of laws giving effect to a market economy. Embracing a market economy is usually associated in political theory with efforts to develop a more open Society and enhancement of the institutions of democratic governance. In Myanmar

10 It is said that neither Prime Minister General Khin Nyunt, nor Vice-Senior General Maung Aye were present at this discussion. 
however, the move to the market has been halting, characterized by substantial continued state intervention, support for a large number of deficit-producing stateowned enterprises (SOEs), and continued authoritarian (military) rule. Those who look to the opposition NLD to usher in a new era of democratic governance see this as the most desirable means of attempting to change the hierarchical nature of Myanmar political culture.

However, this perspective fails to take into account the essentially authoritarian nature of the indigenous state. Myanmar's history, whether that of its earliest classical kingdom at Bagan (850-1287); its $16^{\text {th }}$ and $18^{\text {th }}$ century empires; its democratic welfare state during the era of parliamentary democracy (1948$1958 ; 1960-62)$; or indeed, the colonial state (1886-1948), has projected power through the populace by authoritarian means. Suppression of dissent and jailing of political opponents characterized the earlier experiences with multi-party democracy both during the diarchy period (1937-1940) and the e ra of p arliamentary democracy, as they have during the four decades of military rule. If multi-party elections were held tomorrow, this essentially authoritarian nature of the indigenous Burmese state would not change. The process of turning subjects into citizens (which in Western Europe was well underway throughout the eighteenth century) with political and civil right as well as social and economic rights, has yet to begin in Myanmar. This means that the institutions to support a nonauthoritarians form of governance is to be moderated.

If, in future, Myanmar moves to democratic form of governance based on multi-party elections, the country will need considerable support and assistance in putting in place the institutions which underpin this system. In turn, such a fundamental change presages considerable re-training of civil, judicial, and legislative professionals, and a complementary approach in education, to underpin the sustainability of a viable civil society. The resources required for such a change in political culture are immense, and presently wanting. They will need to come from the international community, which constantly calls on Myanmar to change its form of governance, but, sadly, withholds the resources which might encourage that transformation to evolve.

Myanmar is an overwhelmingly agrarian country with around 70 per cent of its over 50 million people living in rural areas on small subsistence farms. Some 64 per cent of the labour force earns a living from agriculture which p rovides a round $48 \mathrm{per}$ cent of GDP. ${ }^{11}$ The industrial sector, including mining, manufacturing and trade, currently accounts for only around 10 per cent of GDP. This asymmetrical demographic profile means that international sanctions inhibiting the development of the country's trade have limited impact, mostly on the urban poor, mostly women, in low-paid factory jobs, who are thrown into destitution when

11 See H, James. 2003. Co-operation and Community Empowerment in Myanmar in the Context of Myanmar Agenda 21, Journal of Asian Pacific Economic Literature, 17 (1): 121 for a detailed discussion of the demographic implications of this pattern of resource distribution. Statistics come from World Bank. 2002. World Development Report $2000 / 2001$ : Attacking Poverty, New York: Oxford University Press and Asian Development Bank. 2000. Country Assistance Plan (2000-2002) Myanmar, Manila: Asian Development Bank. 
those factories close because their export markets have disappeared. ${ }^{12}$ Sanctions have no effect on the ruling elite. If sanctions are intended to foster democratic governance, then they a re the wrong tool to achieve this end. Sanctions foster extreme nationalism, a return to autarkic modes of economic and political behaviour, and entrench the authoritarian political culture. If the West wishes to support the evolution of democratic governance in Myanmar, it will need to acknowledge that a vastly different approach is required, one which requires more patience, more skill, more investment of resources to foster Myanmar's educational and economic development, and more respect for the capacity of the people to manage their evolution to a modern state.

It is often said that the military in Myanmar is the only institution town. At first glance this assessment appears correct. The Myanmar military is reputed to be over 400,000 strong, with separate educational, health, and training facilities, in fact, a state within a state. ${ }^{13}$ Service in

12 Myanmar is now finding alternate markets for its textile exports in the wake of the most recent round of US sanctions. See Myanmar Times, 20 October 2003.

13 Mary Callaghan. 2001. Soldiers as State Builders, in Muthiah Alagappa. (ed). 2001. Governance and coercion: the declining political role of the military in Asia, Stanford University Press, pp.413-429. Both Callaghan and Alagappa acknowledge that Myanmar, where the military has ruled for over 40 years, is an exception to the general situation in Asia where civilian control of the military is becoming the norm. Andrew Selth. 1996. Transforming the Tatmadaw: the Burmese Armed Forces since 1988, Canberra: Strategic and Defence Studies Centre, The Australian the military thus provides an attractive career, especially for landless rural people; it soaks up unemployment and provides access to training opportunities and social mobility. The gap between the civilian and the military segments of society is a vast problem which a ny r eformist g overnment will have to address. Equally problematic will be the gradual training of the military establishment to accept control by a civilian government, as now appears to be the case in neighbouring Thailand. Such an evolutionary process is likely to take a considerable time in Myanmar, where the military are thought that they are the saviours of the country from the machinations of civilian politicians whose actions in the past have been judged to smack of disloyalty imperiling the survival of the state.

In recent years, there are signs that the government has been seeking to address the perception of mono-institutionalism through actively re-creating the institutions of the pre-colonial indigenous state. Thus, the position of the Buddhist Sangha has been enhanced and made central to all religious and cultural life. ${ }^{14}$ New pagodas have been built: the major temples at Bagan have been the subject of extensive conservation measures. The Shwe Dagon in Yangon, is annually regilded and presented as the central unifying political and religious symbol of the country, as it had been during the Konbaung Dynasty, before the British occupied Rangoon in $1852 .{ }^{15}$ It is here that

National University, provides a detailed analysis of the evolution of the Myanmar military.

14 The Sangha is the term used for the institution of the Buddhist monkhood.

15 When King Mindon wanted to have a new $h t i$, umbrella, installed on the top of the Shwe 
the ceremony to commemorate Aung San and the martyrs of 19 July 1947 is held. Young monks come here to take their oral examinations before a senior monk. The presentation of kathin robes to monks at the end of the rainy season by members of the elite governing group is given extensive media coverage. At the same time, the Sangha is made to serve the state through registration and strict control of monks, who have a history of violent challenge to the central authority, both in contemporary times and during earlier eras. ${ }^{16}$ As an indigenous institution however, the Sangha has again been accorded a central legitimating role as it had been during the monarchical state.

The second major indigenous institution is the state itself, which is sometimes conflated with 'regime.' The supremacy of the state as an institution is apparent in all official documentation. Peace, unity and stability are proclaimed as the state objectives; survival of the unitary state is the priority of the government. For the minority peoples, of which there are over 100 , however, peace, unity and stability is to be achieved through a federated state in which they have the autonomy held out as a promise at the 1947 Panglong agreements brokered by Aung San in

Dagon, as had various previous monarchs of the Konbaung dynasty, the British, aware of the political symbolism of the Shwe Dagon, opposed his intention to pay a personal visit to the shrine.

16 Most recently in Upper Myanmar at Kyaukse, there were disturbances between monks and Muslims. The authorities ordered monks to stay in their temples to avoid the possibility of further disturbances. exchange for their joining the union. ${ }^{17}$ The turbulent history of Burma since 1948 is inseparable from their desires for autonomy. ${ }^{18}$ Approaches to institutional development which ameliorate the essentially authoritarian character of the Burmese-Myanmar state will need to take into account these desires of the minority peoples for a measure of 'home rule', otherwise the longterm survival of the state could again be in jeopardy. Given the government's insistence on a unitary state - a revival of 'federalism' being unlikely the approach being taken, through the cease-fire a rrangements a nd programs for the development of the border regions and minority peoples, suggests that a pattern of administration similar to that which prevailed before the colonial era, might be being considered. This would restore some measure of self-government at the local level, but retain the notion of a centralized state.

In neighbouring Thailand, the three pillars are state, Sangha and monarchy. In Myanmar, where the monarchy was officially abolished in 1886 with the deportation of the last king, Thibaw, and his Queen, Supayalat, to India, the monarchy is reflected in the reconstruction of key palaces associated with the past glories of the Burmese state, in particular the palaces at Mandalay $\left(19^{\text {th }}\right.$ century), Pegu (16 $6^{\text {th }}$ century), and Bagan $\left(11^{\text {th }}\right.$ century), correlating with the three periods of the Burmese empire. These palaces have been painstakingly

17 These involved only three of the major ethnic minorities - the Shan, Kachins, and Chin. They did not, for example, include the Karen.

18 The insurgencies which erupted at independence in 1948 have now been mostly negotiated to cease-fires. The government claims that 19 'arms for peace' arrangement are in place. 
reconstructed from architectural drawings and are a tribute to Myanmar craftsmen. Considerable resources have been expended on the reconstructions which visualize for the present generation the past glories of the indigenous culture. The absent monarchy is thus present in these reconstructions. At Mandalay in November 2002, a Myanmar colleague indicated the plaster replica of King Thibaw seated within the reconstructed palace and said to me, 'That is my king.' Although at various times since 1962 there have been some tentative suggestions that one or other of the military group might assume the monarchical role, it seems increasingly unlikely that such an event will occur. More probable is that the monarchical institution is being subsumed in evocations of the past as the government instead reifies 'the people.' Yet, if 'the people' are to become the third pillar, the reform process, which appears to have intensified following the top structure re-shuffle on 25 August 2003, will need to incorporate the institutionbuilding required to transform 'subjects' into 'citizens'.

\section{The 30 May Incident}

At Depayin, in northern Myanmar, on 30 May 2003, the cavalcade of Daw Aung San Suu Kyi was confronted and attacked by a large group from the Union Solidarity Development Association (USDA), a government mass organization with a membership of some 16 million members. In the ensuring melee, an indeterminate, but reputedly large number of people were killed. It is said that it had been arranged for people to come from Mandalay for this purpose; but they had returned home when they were not paid. Others on hand took over. Rumours immediately circulated that Daw Aung San Suu Kyi had been seriously hurt; and that General Tin Oo had been killed. As it turned out, neither of these rumours were accurate. However, the two leaders of the NLD were taken into protective custody along with some 35 of their supporters. Eight were subsequently released.

This incident caused international outrage, leading to universal calls for Daw Aung San Suu K yi's release and led the US to impose tighter sanctions which impacted on the country's textile exports and capacity to conduct international trade. Amongst the higher government echelons, there was much 'finger-pointing' to cast 'blame' for the tragedy; and for the extremely precarious position which resulted for the country. For a time the fall-out derailed the reform program which had been chogging along gradually since 1997. It most certainly precipitated the top structure changes announced on 25 August, as a desperate effort by the government group regain control of the situation. A diplomatic flurry, including speeches to the UN by the Foreign Minister, U Win Aung, and other senior Foreign Minister officials, was launched to repair the damage.

On 9 November 2003, the official announcement that there were no restrictions on Daw Aung San Suu Kyi's freedom came as almost an anti-climax. Following successful surgery for a gynaecological condition, she had been recuperating at home for some weeks. In early October, Foreign Minister, U Win Aung, was quoted as saying that she was not under house arrest; a few days later, Daw Aung San Suu Kyi herself was quoted as saying that she was satisfied with the protection being accorded. In the wake of the violence, the government had some concerns that her safety might be at 
risk from certain elements in the country. However, confirmation of her status came as almost an anti-climax; it was not covered in the local press, which concentrated on the state visit by the VicePresident of India and his high level delegation, and on the government round of ceremonial activities, including visits by key senior members of the SPDC to elementary schools in the area of Upper Myanmar where the 30 May incident took place. Daw Aung San Suu Kyi herself was quoted as saying that she would not 'accept freedom' until all of her followers, taken into custody at the time of the incident, were released. ${ }^{19}$

\section{Significance of the Top Structure Changes}

The disarray in the senior echelons of the Myanmar government caused by the fallout from the 30 May incident provided the impetus for General Khin Nyunt's elevation to the Prime Ministership. It was widely seen as a tactical move to preserve stability and power at a time when the country was rocked by economic crisis and international pressure. Viewed as a reformer who has driven Myanmar's reengagement with the international community, General Khin Nyunt brings to the office not only his experience as former Secretary-1 in charge of the military intelligence services and the operational running of the country, but also experience gained in international affairs during the time when he served closely the late General Ne Win, whom he accompanied on international visit. As Secretary-1, General Khin Nyunt had been chair of many of the key high level co-ordinating committees and kept his

19 The Sydney Morning Herald, 9 November 2003. hand on the pulse of all policy matters. His move to become Head of Government, reportedly mooted even prior to 30 May 2003, now gives him responsibility for driving the processes which are to return Myanmar to democratic governance. His personal credibility is now on the line, a factor which will assist greatly in making sure it happens. However, the return to democratic governance will be 'Myanmar style', as made clear in his 'State of the Union' speech on 30 August 2003.

\section{The Seven Point Plan to Restore Democracy}

The new Prime Minister's seven point plan to return democratic rule to Myanmar, as announced on 30 August, envisages that the National Convention, suspended since 1996, will be reconvened as the first step in a process leading to what he styles 'genuine disciplined democracy.' The national convention will be tasked with drafting a new constitution. A referendum will then be held preparatory to the new constitution being adopted. When this process is completed, 'free and fair elections' will be held to elect representatives to the Pyithu Hluttaws (Legislative assemblies); then the Hluttaws (Pyithu and Amyotha, the Assembly of the Nationalities) will be convened. These steps are seen as the building blocks for a 'modern developed democratic nation.' These steps were reaffirmed during the press conference following the Prime Minister's speech.

Omitted from the plan, and side-stepped during question time following it, are any indication of a timeframe for the process to be completed; clarification on whether the 'free and fair elections' are multi-party elections, or only single-party elections along the lines of those held during the 
socialist era; what role the minority peoples will have in these processes; and whether the NLD will be included in the processes. The Prime Minister's responses at question time made it clear that he did not wish to stipulate a timeframe, even though many commentators pointed out that this was a weakness in the plan which had lead its critics to label it 'old wine in new bottles'. Nevertheless, in September 2003 steps were quickly taken to set in place the a dministrative arrangements for re-convening the National Convention and appointments were made to two high-level support committees. Rallies were also held around the country, by the USDA, in support of the plan.

Whether the plan succeeds or not will depend largely on the role the minority peoples play. As soon as it was announced, various minority groups also put forward their own 'plans' and made it clear that they must participate in the processes, if these processes are to have any credibility. This will be a useful experience for Myanmar leaders in managing 'participative practices', a political concept which has not been in evidence in Myanmar's authoritarian political anthropology. In November, three key minority groups announced they would participate in the National Convention processes. At issue is how they will participate, their motivations, and interactions, participation could be with the objective of de-railing a process whose likely outcomes do not suit their goals.

Foreign observers are watching too, to see what role, if any, the NLD will have. The NLD in 1996 walked out of the National Convention processes, then, when they tried to return, were excluded. The Prime Minister's responses at question time made it clear that the NLD will not have a role in these processes, despite calls from international supporters for the NLD to be included. At the time the Constitution drafting processes were suspended in 1996, some 104 principles has been 'agreed'. These included mandatory requirements for the Head of State/Head of Government to have been resident in the country for a continuous period of 20 y ears; $n$ ot (ever) married to foreigner; not have any relative married to a foreigner. ${ }^{20}$ It has been noted that these principles would exclude Daw Aung San Suu Kyi from eligibility since, prior to 1988, she had been resident in England (and has now been continuously resident in Myanmar for 15 years) and had been married to an Englishman, the late Tibetan specialist, Michael Aris.

There is no doubt that arrangements are pressing ahead for re-convening the National Convention, and expediting the processes leading to a new Constitution. Some of the minority groups also appear to be being included in the processes. But there are many difficult issues to be addressed, not the least of which is the role, if any, of the NLD.

Given Myanmar's authoritarian political culture, lack of experience with multiparty democracy, and announced penchant for 'disciplined democracy', it is likely that the processes described above will lead, in the initial phase, to e ither a oneparty system controlled by the military government in which the military representatives each has two votes as part of an electoral college system; or that the 'multi-parties' which contest the elections will in fact be government-empathetic parties. There are presently reported to be

20 With these principles in mind, the Prime Minister publicly disowned his son who married a Singaporean. 
10 parties (excluding the NLD) which are registered to participate in any elections which might be held.

The shape of the Myanmar government then, o ver the n ext five years, is likely to show a gradual assumption of some of the institutional framework of democratic governance, in accordance with international expectations of how a modern state should function, but still maintain military control of the apparatus of government. With support from its ASEAN neighbours, and China and India, such a gradual transformation many enable the government to improve the socioeconomic $\mathrm{c}$ redentials of the country, thus providing the resources for continued political evolution in the following phase. ${ }^{21}$ The role that neighbouring Thailand and Malaysia can play in brokering this transformation will be critical. I do not envisage that Myanmar will move to 'phase two' of democratic governance - that presently exhibited in Thailand where the military has stepped back from dominance of public life and accepts civilian control - until the country has established working experience with the basic institutions, the new constitution, and multi-party elections leading to a peaceful passage of power. This transitional process would take, I believe,

${ }^{21}$ During the state visit of the Vice-President of India, on 2 November, India provided a loan of USD57 million to Myanmar for upgrading of the Yangon-Mandalay railroad. At the 12 November 2003 four nation economic summit held at Bagan, between Thailand, Myanmar, Laos and Combodia, Thailand sponsored discussions for the economic development of its less prosperous neighbours. China announced a further USD200 million investment in Myanmar to improve electricity generation capacity at the same time as the US president was putting in place further economic sanctions. between five to ten years, a timeframe allowing for the country's economic development to grow to such a level that it can support the institutional transformation required for democratic governance.

\section{Conclusion}

So, will Myanmar be a dancing or a stricken peacock? Skilful implementation of the Prime Minister's seven point plan to return Myanmar to democratic governance will be only part of the evolutionary change required. Learning the art of compromise, so necessary to implanting a democratic tradition, will be a steep learning curve for Myanmar. All parties in the conflict have shown a propensity to view the world only through their own lens and to claim that only they can be the country's saviours. But it will take a lot of 'learning to live together' ${ }^{22}$ for the contending parties in Myanmar to truly put the interest of the nation - and the future of the younger generation - before their own interests.

\section{References}

Alagappa, M. 1995. Political Legitimacy in Southeast Asia: the Moral Question, Stanford: Standford University Press.

Alagappa, M. 2001. Governance and Coercion: the declining political role of the military in Asia, Stanford: Standford University Press.

22 U Than Aung. Minister for Education, Preface, Quoted in U Han Tin. 2000. Myanmar Education: Status, Issues and Challenges, Journal of Southeast Asian Education, (1): 132-60. 
Asian Development Bank. 2000. Country Assistance Plan (2000-2003) Myanmar, Manila: Asian Development Bank.

Callaghan, M. 2001. Soldiers as State Builders, in Alagappa. M. 2002, Governance and Coercion: the declining political role of the military in Asia, Stanford: Standford University Press.

Htin Aung. 1965. The Stricken Peacock: Anglo-Burmese Relations 17521948, The Hague: Nijhoff.

Htin Aung. 1990. Lord Randolph Churchill and the Dancing Peacock: British Conquest of Burma, 1885, Daryaganj, India: Manohar.

James, H. 2003. Cooperation and Community Empowerment in Myanmar in the context of Myanmar Agenda 21, Journal of Asian Pacific Economic Literature, 17(1): 1-21.

Myanmar Times, 5 October 2003.

Myanmar Times, 2 November 2003.

Myanmar Times, 12 November 2003.

Myanmar Times, 20 November 2003.

Sydney Morning Herald, 8 October 2003.

Sydney Morning Herald, 9 November 2003.

Selth, A. 1996. Transforming the Tatmadaw: the Burmese Armed Forces since 1988, Canberra: Centre for Strategic and Defence Studies, The Australian National University.

Taylor, R.H. 1987. The State in Burma, Honolulu: University of Hawaii Press.

U Han Tin. 2000. Myanmar Education: Status, Issues and Challenges, Journal of Southeast Asian Education, (1): 132-60.
World Bank. 2002. World Development Report 2000/2001: Attacking Poverty, New York: Oxford University Press. 